\title{
Pioneiros do vídeo e do cinema experimental na América Latina
}

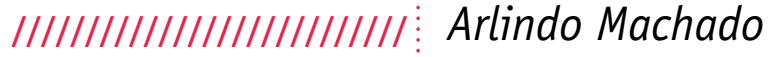

PUC/SP, ECA/USP 


\section{Resumo}

Há carência de pesquisas e de dados sobre a história do vídeo criativo e do cinema experimental na América Latina, principalmente sobre a sua "pré-história", ou seja, o período anterior ao surgimento "oficial" do cinema experimental e da vídeo-arte em todo o mundo (anos 1960). Este artigo pretende ser apenas o início de uma longa investigação em direção à necessária recuperação de uma história que ainda está para ser contada. Ao mesmo tempo, nós nos perguntamos sobre o que pode significar uma obra experimental num contexto latino-americano e o que a diferencia das experiências realizadas em outros contextos.

\section{Palavras-chave}

Cinema experimental, vídeo-arte, América Latina, audiovisual latino-americano.

\section{Abstract}

There is a lack of research and data on the history of creative video and experimental cinema in Latin America, specially on its "prehistory", in other words, the period prior to the "official" appearance of experimental cinema and video art worldwide (1960s). This article aims to be a beginning of a long path towards a necessary restoration of a history still to be told. At the same time, we ask ourselves about what it can be an experimental work in a Latin American context and what differentiates it from the experiences made in other contexts.

\section{Key-words}

Experimental cinema, video art, Latin America, Latin American audiovisual. 
Falar do vídeo e do cinema experimental na América Latina significa falar de um duplo deslocamento. De um lado, porque é latino-americano, esse cinema e esse vídeo sofrem a maldição de um quase completo desconhecimento: não há distribuição, não há acesso às obras (quando existem, pois muitas já desapareceram), a informação existente é mínima e a crítica ou a análise são quase nulas. Tudo isso porque o foco das atenções do mundo não está voltado para esse lugar neste momento (alguma vez esteve?). De outro lado, por ser experimental e não visar uma inserção comercial, esse cinema e esse vídeo já são naturalmente excluídos em todo e qualquer lugar do mundo, inclusive nos países de produção audiovisual hegemônica. Imagine-se então o que acontece no lugar da exclusão propriamente dita: a América Latina. Referindo-se ao cinema de longa-metragem, Paulo Paranaguá, em seu Tradición y Modernidad en el Cine de América Latina, afirma que os filmes da América Latina, "son minorías suprimidas, desaparecidas, sin derecho a velorio ni duelo, como tantos difuntos del continente" (2003, p.14). Podemos então imaginar o que acontece com a produção audiovisual não estandardizada, com temáticas e estilos que escapam às regras do mercado internacional, além de realizada em bitolas e formatos não comerciais. Poderíamos então definir essa produção audiovisual pela sua condição de quase absoluta invisibilidade.

No entanto, esse cinema e esse vídeo existem e existem numa proporção e qualidade que impressionam os (poucos) que se dedicam à aventura de buscá-los, estejam onde estiverem. Ultimamente, 
entretanto, estão surgindo algumas tentativas de buscar, mapear e sistematizar informações sobre essa produção invisível, mas vigorosa. O projeto Videografías Invisibles (2005), uma produção conjunta da Espanha e do Peru sob a curadoria dos peruanos Jorge Villacorta e José-Carlos Mariátegui, é um dos esforços mais extensivos nessa direção. Compreende uma mostra de 41 trabalhos de cerca de 50 realizadores, abrangendo quase todos os países latino-americanos, e também um livro-catálogo rico de informações. Em 2008 foi lançada no Brasil a mostra Visionários: Audiovisual na América Latina (Moreira Cruz, 2008), com curadoria de Arlindo Machado (Brasil), Jorge La Ferla (Argentina), Marta Lucía Velez (Colômbia) e Elias Levin Rojo (México), abrangendo 67 trabalhos de realizadores de toda América Latina, sejam eles contemporâneos ou históricos. Essa mostra, a exemplo também de Videografías Invisibles, correu grande parte dos países da América Latina (e também da Europa) durante vários anos, acompanhada de um livro-catálogo em três línguas. E recentemente, saiu também na Espanha o livro Video en Latinoamérica: una Historia Crítica (2008), organizado por Laura Baigorri, com a participação de cerca de 20 críticos, curadores e realizadores de toda a América Latina. A distribuição internacional desse livro também está sendo acompanhada por uma mostra, com curadoria da própria Laura Baigorri, abrangendo uma parte significativa da produção de vídeo na América Latina. Vale lembrar ainda a mostra e o seminário Cine a Contra Corriente: Latinoamérica y España, especificamente sobre o cinema experimental na América Latina, que um grupo de especialistas está preparando para outubro de 2010 em Barcelona.

Paralelamente a isso, tem havido também muitos esforços de mapear a produção audiovisual de países específicos da América Latina, como é o caso do projeto Made in Brasil (MACHADO, 2003; livro e mostra), abrangendo o vídeo brasileiro desde seus primórdios até o começo do século XXI; o livro Historia Crítica del Video Argentino (LA FERLA, 2008), abrangendo toda a história da produção videográfica na Argentina; a série de mostras Fast Foward, com curadoria de Luisa Marisy, sobre a produção cubana de vídeo e cinema experimental; a mostra e o livro-catálogo La Condición Video (AGUERRE, 2007), sobre os 25 anos de vídeo-arte no Uruguai e muitas outras iniciativas que seria cansativo enumerar aqui. Embora ainda modestos em alcance, esses projetos estão permitindo aos seus promotores 
correr toda a América Latina em busca das informações dispersas e também em busca de contato direto com as obras e os realizadores, evitando dessa forma trabalhar em cima dos poucos documentos existentes, para não correr o risco de repetir o que já se sabe. Como resultado, vem à luz uma América quase desconhecida, além de enigmática e surpreendente em sua luxuriante diferença.

O que é o experimental? Até os anos 1960 os filmes costumavam ser classificados como "documentários" ou "ficções" e não havia muita margem de manobra para sair dessa dicotomia simplificadora. Mas havia uma produção emergente, em volume cada vez mais expressivo, sobretudo fora do circuito comercial, que em hipótese alguma cabia nessa classificação obsoleta. Quando Stan Brakhage começa a fazer filmes colando asas de borboleta sobre uma película em branco, sem nem sequer obedecer aos limites do fotograma, já não era mais possível manter impunemente a dicotomia tradicional. Foi então tomado o termo "experimental" para designar esse campo até então excluído do audiovisual. Mas o curioso é que o “experimental” só pôde ser conceituado por sua exclusão, por aquilo que ele tem de atípico ou de não-padronizado, por aquilo, enfim, que não se define nem como documentário, nem como ficção, situando-se fora dos modelos, formatos e gêneros protocolares do audiovisual. O termo foi adotado com base no uso que já se fazia dele no cinema underground norte-americano a partir de finais dos anos 1950. Antes, principalmente nos anos 1920, utilizava-se o termo avant garde para designar propostas desse tipo. No campo do vídeo, o equivalente do cinema experimental era a vídeo-arte, que tinha horizontes e propostas estéticas semelhantes.

Naturalmente, o conceito de experimental envolve mais coisas que a simples demarcação de uma diferença com relação à produção audiovisual estandardizada. Como sugere o próprio nome, a ênfase desse tipo de produção está na experiência, no sentido científico de descoberta de possibilidades novas. Jairo Ferreira (1986, p.27) prefere falar de um cinema de invenção, "um cinema interessado em novas formas para novas idéias, novos processos narrativos para novas percepções que conduzam ao inesperado, explorando novas áreas de consciência, revelando novos horizontes do im/provável”. Outros, como Sheldon Renan (1970, p.1), preferem falar de um cinema "subterrâneo" (underground), "uma explosão de estilos, formas e diretrizes cinematográficas”. Já Gene Youngblood (1970) opta pela 
expressão cinema expandido, que seria uma espécie de cinema lato sensu, seguindo a etimologia da palavra (do grego kínema - ématos + gráphein, "escrita do movimento"), que inclui todas as formas de expressão baseadas na imagem em movimento, preferencialmente sincronizadas a uma trilha sonora. Observando o que estava acontecendo ao seu redor, principalmente no âmbito do cinema experimental underground, Youngblood percebe que o conceito tradicional de cinema havia explodido. Alguns cineastas faziam filmes para serem projetados não mais em telas, mas nas roupas brancas de bailarinas em situações performáticas; Ken Jacobs propõe um filme (Tom Tom, the Piper's Son/1969) em que parte dele deveria ser projetado com a película fora da grifa e, portanto, sem exibição dos fotogramas; Andy Warhol concebe o seu Chelsea Girls para duas telas paralelas e simultâneas, resgatando a experiência de Abel Gance com seu Napoléon; alguns filmes já não eram mais feitos com câmeras, mas diretamente modelados e animados em computadores (como toda a obra dos irmãos Whitney), enquanto outros (os de Nam June Paik, por exemplo) não usavam mais películas, mas fitas eletromagnéticas e eram exibidos em aparelhos de TV. Portanto, o conceito de cinema havia expandido e podia então designar fenômenos audiovisuais que até então não cabiam em seus estreitos limites.

Na América Latina, o percurso do "experimental" teve desenvolvimentos muito variados e diferentes, dependendo do país onde a questão se colocou. A vídeo-arte chega muito cedo a países como Argentina, Brasil e México. Em outros, só nos 1980, ou até mesmo no começo dos 1990. No Brasil, a primeira geração de vídeo-artistas trabalha com equipamento amador, sem recursos de edição, em condições de semi-clandestinidade. Já num país como a Venezuela, onde o vídeo surge um pouco mais tarde, os trabalhos já nascem profissionais, com recursos tecnológicos das televisões públicas, que abrem para os realizadores os seus estúdios no horário noturno. Um país como Cuba, por sua vez, teve uma extraordinária experiência com a cinematografia experimental, em grande parte dos casos de forma independente, tendo adotado o $16 \mathrm{~mm}$ como a sua bitola predileta, pelo baixo custo, maior facilidade de exibição e até mesmo pela autonomia que proporcionava em relação ao sistema vigente. Um cineasta como Juan Carlos Alom, por exemplo, revela, copia e edita em casa os seus filmes, sem passar pelos laboratórios e salas de montagem, tradicionais locais de controle e vigilância, sobretudo, 
como é o caso, num país como Cuba. Países como a Venezuela e o México (Brasil e Argentina também, numa proporção um pouco menor) conheceram um extraordinário desenvolvimento do super-8, chegando mesmo a manter uma produção expressiva de longa-metragens nessa bitola, como é o caso da obra de Diego Risquez, na Venezuela. No Uruguai, a partir dos anos 1980, ou seja, a partir da decadência da ditadura militar, a cinematografia estava praticamente aniquilada e o vídeo preencheu essa lacuna. Os uruguaios chegaram a fazer até longa-metragens em vídeo, embora sempre experimentais, e os exibiam em salas de vídeo que simulavam as de cinema, talvez já antecipando em décadas as atuais salas de cinema com projeção eletrônica.

Entretanto, faltam pesquisas, faltam dados sobre a história do vídeo criativo e do cinema experimental na América Latina, principalmente sobre a sua "pré-história", ou seja, o período anterior ao surgimento "oficial" do cinema experimental e da vídeo-arte em todo o mundo (anos 1960). Enquanto nenhuma prova em contrário apareça, Limite (1930), filme brasileiro de longa-metragem em $35 \mathrm{~mm}$ de Mário Peixoto, é provavelmente o marco inaugural do cinema experimental na América Latina, mesmo que esse termo ainda não estivesse em circulação naquela época. Limite poderia ser definido como um filme líquido, não apenas porque a maior parte de suas cenas se passa em mar aberto, mas também porque, à medida que o filme avança, as imagens vão se liquefazendo, se desmanchando, até a abstração total. Uma cópia restaurada de Limite foi exibida no Festival de Cannes em 2007 provocando estupefação numa platéia predominantemente européia, incapaz de compreender como se pôde fazer vanguarda ou experimentalismo num país periférico, situado fora dos centros hegemônicos da cultura e ainda por cima em 1930! Mesmo uma estudiosa comprometida com a produção experimental, como é o caso da norte-americana Annette Michelson, considera Limite uma espécie de exaustão da avant garde (apud Adriano, 2007, p.16). Para os olhos colonialistas do primeiro mundo, a América Latina parece condenada apenas a filmes e vídeos sociológicos, que tematizam o seu próprio subdesenvolvimento.

Depois de Limite, há três exemplos remotos de cinema experimental na América Latina. O primeiro não se sabe bem se pode ser considerado um produto latino-americano, pois é uma co-produção 
argentina e alemã, dirigida por Horacio Cappola (conhecido fotógrafo argentino) e Walter Auerbach (alemão). Trata-se de Traum (Sueño, em espanhol), realizado em Berlim em 1933 com película de $16 \mathrm{~mm}$. Um homem (Walter Auerbach), caído sobre uma mesa, dorme e manifesta gestos de quem está sonhando. Através de recursos de animação, objetos aparecem e desaparecem em sua mesa durante o sonho, inclusive a foto de uma mulher e uma nota de dinheiro. Outro personagem aparece e furtivamente lhe rouba a foto e o dinheiro. Quando um close up o identifica, vemos, surpresos, que é o mesmo homem que dorme, como se fosse o seu double. Começa então uma perseguição, em que o primeiro finalmente agarra e nocauteia o seu sósia. O filme termina com o vencedor abraçado com a moça da foto, os dois caminhando em direção ao fundo do quadro. Uma espécie de William Wilson (Edgar Allan Poe) com um final chapliniano e feliz.

Outro exemplo é Esta Pared No Es Medianera, um curta-metragem em $16 \mathrm{~mm}$ realizado pelo peruano Fernando de Szyszlo em 1952. Artista plástico já consagrado no Peru e em todo o mundo, mais identificado com a arte não-figurativa, de Szyszlo logrou com esse filme uma curiosa experiência com cinema experimental, que lembra remotamente o cinema surrealista do período mudo (Buñuel, principalmente). O filme acabou desaparecendo por longo tempo, mas recentemente foi descoberta uma cópia em VHS que, segundo o próprio autor, está incompleta, como é o caso também da cópia remanescente de Limite, que seu autor advogava, durante toda sua vida, estar incompleta.

O terceiro exemplo é La Langosta Azul (1954), filme colombiano creditado ao jornalista e cineasta Álvaro Cepeda Samudio e ao célebre escritor Gabriel García Márquez. Embora muitos considerem que a concepção e a direção são devidas mais a Samudio, não se pode esquecer de que, nessa época, o jovem jornalista García Márquez tinha sonhos de tornar-se cineasta e chegou a estudar cinema na Itália, no prestigioso Centro Sperimentale di Roma. Frustrado em seus sonhos cinematográficos, muito tempo depois ele fundaria em Cuba a famosa Escuela de Cine y TV de San Antonio de los Baños, enquanto Cepeda Samudio, por sua vez, continuaria sua carreira de cineasta. O filme ficou cerca de quarenta anos sem exibição, porque foi realizado em película de $16 \mathrm{~mm}$ reversível, portanto em cópia única, sem negativo. Cada exibição 
produzia danos na única matriz do filme. Finalmente, em 1990, um internegativo foi providenciado para uma exibição em Nova York e o filme pôde voltar à circulação.

La Langosta Azul é resultado dos encontros do chamado Grupo de Barranquilla, composto por Cepeda Samudio, García Márquez, o artista plástico Enrique Grau e outros que circulavam ao redor. O filme é mudo, mas visualmente muito eloqüente, de modo que não necessita de palavras para explicá-lo. Ele mistura duas coisas quase impossíveis de estarem juntas. De um lado, há uma estranha história de um forasteiro (o "gringo") que vai a uma comunidade de pescadores em busca de exemplos de contaminação das lagostas azuis por radiação atômica, o que parece configurar uma espécie de ficção científica. De outro, essa história muitas vezes se perde e o filme se fixa na vida cotidiana dos pescadores, quase como um documentário direto. Alguns personagens são cômicos (o recepcionista do hotel que está sempre enchendo bexigas, ou o voyeur que, com sua luneta, espia tudo o que se passa no vilarejo), outros trágicos (o "gringo") e outros simplesmente "naturais" (o pescador). Há uma ênfase exagerada em detalhes absurdamente pequenos e que não estão em compasso com a(s) história(s) que está(ão) sendo contada(s), a ponto do plot narrativo resultar quase abstrato. Enfim, temos aqui uma estrutura semi-narrativa que já prenuncia todo o posterior desenvolvimento do cinema experimental dentro ou fora da América Latina.

Em 1958, o brasileiro Glauber Rocha inicia a sua ruidosa carreira cinematográfica com um curta-metragem em $35 \mathrm{~mm}$, O Pátio, filme quase abstrato, rigorosamente encenado e com fortes referências do construtivismo e da arte concreta, além de dialogar com Limite. Não se sabe se Rocha chegou a ver Limite nos anos 1950, considerando que este filme ficou fora de circulação durante várias décadas, mas a mão de Mário Peixoto está lá, seja direta ou indiretamente, malgrado, anos depois, Glauber atacaria Limite como um exemplo de cinema individualista pequeno-burguês. Na verdade, tendo posteriormente mudado completamente a sua estética e adotado um estilo barroco e anárquico, Rocha atacaria Limite como uma forma de atacar-se a si próprio e desautorizar O Pátio, de cujas experiências formais ele se afastaria cada vez mais. Mas o filme é poderoso em seu rigor geométrico e sua estranha visualidade. Num terraço de azulejos em forma de xadrez, em Salvador, um rapaz e uma moça (Sólon Barreto e Helena Ignez) evoluem lentamente: se tocam, rolam pelo 
chão, se distanciam e se olham. Os planos das mãos e dos rostos são intercalados com planos da vegetação tropical e do mar, ao som de fragmentos de música concreta, recém inventada na França por Pierre Henry e Pierre Schaeffer. Infelizmente, experiências como Limite e O Pátio não tiveram continuidade no Brasil, a não ser remotamente na obra do também experimental Júlio Bressane.

Em 1962, o cineasta boliviano Jorge Sanjinés lança seu primeiro curta-metragem, Revolución, em $16 \mathrm{~mm}$, iniciando uma verdadeira revolução no cinema latino-americano, que depois se aprofundaria em obras como Aysa (1965), Ukamau (1966), Yawar Mallku (1969), entre outras. Utilizando apenas imagens, música e sons naturais, Revolución se baseia nas técnicas de montagem conceitual e dialética ("por conflitos") do diretor russo-letão Serguei Eisenstein para compor um ensaio sobre a exploração e a miséria do povo boliviano e sobre as possibilidades de superação através de estratégias revolucionárias. Já se percebe ali a força de um dos cineastas mais originais da América Latina. As imagens e os sons são de uma eloquiência espantosa: não é preciso nenhum discurso verbal para entender o que Sanjinés está querendo dizer. Como no Eisenstein de ¡Que Viva México! (1931), ou no Orson Welles de It’s all True (1942/1993), por coincidência duas malogradas incursões na América Latina, cada plano tem a força expressiva de um mural de Orozco, Rivera ou Portinari. Um resultado semelhante foi obtido no mesmo ano pelo realizador argentino Alberto Fischerman, principalmente com seu curta em 16 mm Quema, um filme visualmente impactante, politicamente implacável, só perturbado por um comentário off que lhe retira um pouco a força.

Surge então Cosmorama, radical curta-metragem em $16 \mathrm{~mm}$ do cineasta cubano Enrique Pineda Barnet, realizado em 1964, a partir de alguns rolos de filme virgem que o cineasta recebeu do ICAIC (Instituto Cubano de Arte e Indústria Cinematográficos) para testar a qualidade. Pineda Barnet é possivelmente o mais inquieto dos cineastas cubanos, com uma obra extraordinariamente diversificada, imprevisível e sem concessões, lembrando um pouco a postura de um Jean-Luc Godard no ambiente europeu. Essa obra inclui coisas como um clássico do cinema cubano (La Bella de la Alhambra/1989), um semi-documentário sobre a relação dos jovens com a revolução castrista (Juventud, Rebeldía, Revolución/ 1969), uma hilariante paródia do plano econômico de Fidel Castro 
para incrementar a produção agrícola em Cuba (Ñame/1970) e até mesmo uma das primeiras experiências cinematográficas com vídeo digital em Cuba (Te Espero en la Eternidad/2007). Cosmorama é o nome da mais famosa obra de arte cinética do artista Sandú Darié, nascido na Romênia em 1906 e falecido em Cuba em 1991. O filme de Barnet é baseado nessa obra de Darié e ao mesmo tempo uma homenagem ao introdutor da arte abstrata e cinética em Cuba. Trata-se de um "poema espacial”, como diz o subtítulo do filme, com formas e estruturas em movimento, com luzes e cores que produzem imagens plásticas em constante desenvolvimento. A trilha sonora de alta complexidade é resultado da mixagem de 13 diferentes pistas de som, onde se incluem peças contemporâneas de Bela Bartok, Pierre Henry, Pierre Schaeffer e Carlos Farina, associadas a ruídos naturais ou mecânicos. Embora realizado em película cinematográfica, esse filme é considerado pelos vídeo-artistas como o precursor da vídeo-arte em Cuba. A película, que se encontrava em avançado estado de deterioração, foi recentemente recuperada graças ao incansável esforço da crítica e curadora Luisa Marisy para dar visibilidade à produção experimental cubana.

Da Argentina vêm dois clássicos do cinema experimental latinoamericano. O primeiro é La Flecha y un Compas, de David Cohon, realizado ainda nos idos de 1950. Planos inclinados ou insólitos, efeitos de fusão sobre imagens da cidade de Buenos Aires, inscrições expressionistas nas paredes e jogos de espelho escondem o drama de um suicida potencial, enquanto os círculos de sua vida se fecham com um compasso. Já Come out (1975), de Narcisa Hirsch, é constituído de um único plano-sequiência de 22 minutos. Como o filme foi feito em 16 mm, evidentemente não é um plano-seqüência de verdade: ele tem cortes dissimulados que, todavia, não prejudicam o efeito. Primeiro aparece uma imagem impossível de identificar porque está inteiramente fora de foco, acompanhada por um som repetitivo, que no final se revela como uma agulha de toca-discos patinando sobre um disco de vinil furado. Há ecos nesse curta do célebre Wavelenght (1968) de Michael Snow, considerado a maior referência do cinema experimental norte-americano e também uma interminável zoom-in de 45 minutos sobre uma paisagem banal de Nova York.

A maioria dos trabalhos produzidos pela primeira geração de realizadores de vídeo brasileiros consistia basicamente no registro do gesto performático do realizador. Dessa forma, consolida-se o 
dispositivo mais básico do vídeo: o confronto da câmera com o corpo do artista. Num dos trabalhos mais perturbadores do primeiro período (Marca Registrada/ 1975), Letícia Parente bordou com agulha e linha as palavras "Made in Brasil" sobre a própria planta dos pés, apontada para a câmera num big close up. Essa obra limítrofe apontaria claramente um caminho de radicalidade sem concessões e marcaria para sempre a história do vídeo brasileiro. Experiências como essa de Letícia Parente, que foram emblemáticas do primeiro período, faziam eco com uma certa ala do vídeo norte-americano da mesma época, representada por gente como Vito Acconci, Joan Jonas e Peter Campus, cuja obra consistiu como observou na época Rosalind Krauss (1978, p.43-64) - em colocar o corpo do artista entre duas máquinas (a câmera e o monitor), de modo a produzir uma imagem instantânea, como a de um Narciso mirando-se no espelho.

Alguns trabalhos viscerais foram produzidos nessa direção no primeiro período do vídeo brasileiro. Sônia Andrade, por exemplo, realizou quase uma dezena de experimentos de curta duração que podem ser incluídos entre os mais maduros de sua geração. Neles, ora o rosto da artista é totalmente deformado por fios de nylon, até transformar-se num monstro, ora a artista se impõe pequenas mutilações, tosando os cabelos do corpo com uma tesoura, ora ainda ela prende a própria mão numa mesa com pregos e fios. São trabalhos de uma auto-violência latente, meio real e meio fictícia, através dos quais Andrade discorre sobre os tênues limites entre lucidez e loucura que caracterizam o ato criador.

Dois nomes fundamentais na construção da vídeo-arte latinoamericana são os da venezuelana Nela Ochoa e do colombiano Gilles Charalambos, ambos também analistas da produção videográfica de seus países, além de artistas bastante originais. Ochoa é uma pioneira da arte do vídeo na Venezuela, mas também trabalha com dança, coreografia, pintura, vídeo-escultura, instalações e, mais recentemente, obras que lidam com biologia e genética. Duas questões são básicas em toda a obra da artista: a relação do corpo com seu entorno e o gesto como forma expressiva primordial do homem, o que poderia ser resumido na idéia de embodiment. Considerando que, para grande parte das ciências contemporâneas, as atividades cognitivas do homem são inseparáveis de seu corpo, embodiment diz respeito ao corpo não no sentido fisiológico do termo, mas como uma pre- 
sença no mundo que é precondição da subjetividade e da interação com o entorno. Em outras palavras, embodiment é o corpo entendido como uma "interface" entre o sujeito, a cultura e a natureza.

Dentre cerca de duas dezenas de obras realizadas em vídeo, um dos trabalhos que mais se destaca na obra de Ochoa é Que en Pez Descanse (1986). Essa peça trata das vivências de uma mulher cuja infância esteve rodeada de gestos e ritos religiosos, onde se misturavam tradições e crenças de origem popular, como aquela que ditava: "todo aquele que se banhar na Sexta Feira Santa se transformará em peixe (pez, em espanhol)." Trata-se de um vídeo poderoso visualmente, com uma mise-en-scène ritualística e alguns toques buñuelianos, além de uma coreografia rigorosa que transforma os movimentos dos atores num verdadeiro balé.

Gilles Charalambos, por sua vez, é o nome que mais se identifica com a história do vídeo na Colômbia. Além de realizador, desenvolve também intensa atividade crítica e de curadoria, sempre relacionados com as artes eletrônicas de seu país. O site Historia del Videoarte en Colombia (http://www.bitio.net/vac/), organizado por ele, é a mais completa coleção de materiais escritos para se conhecer o percurso do vídeo na Colômbia. Já a obra artística de Charalambos é das mais radicais e sem concessões em termos de América Latina inteira. A maior parte dos seus vídeos é constituída de ruídos, distorções, grafismos, pulsões rítmicas, com predominância de imagens não-figurativas e constante referências à televisão e a temas das ciências contemporâneas. Distorsión, Intermitencia, Violencia en esta Información (1979), por exemplo, é um vídeo feito à base de ruídos e desestabilização do sinal eletrônico. Por sua vez, Azar Byte Memory Sens (1984), En el Estilo de... (1984) e No Entendo ni... (1984), realizados em parceria com Edgar Acevedo, são trabalhos conceituais que podem ser considerados como as primeiras obras de arte computacional elaboradas na Colômbia. Personalmente TVideo (1985), em parceria com Pablo Ramírez, é uma reflexão sobre a TV do ponto de vista da vídeo-arte e foi transmitido na própria televisão, através do canal Cadena 3.

oo:05:23:27 (1994/99) é um vídeo inteiramente realizado por Charalambos (direção, concepção, efeitos, edição e música). A obra, que utiliza imagens tomadas em vários lugares do mundo e efeitos gráficos de toda espécie, é um estudo rítmico de várias cadências, com insólitas propostas de sincronização imagem-som, 
além de referências esparsas a conceitos da física, biologia e psiquiatria. O vídeo é acompanhado de um texto lido em alta velocidade e com distorções que o tornam quase ininteligível, a não ser com muito esforço do espectador. Esse texto funciona como uma espécie de metalinguagem do próprio vídeo, como se fosse a sua "explicação", ou a chave de sua decifração. O texto completo é o seguinte:

Este video utiliza una frecuencia de edición con cambios cada cinco cuadros, una velocidad de seis intermitencias por segundo; produce fases de ondas cerebrales en ritmo teta. Éste se parece mucho al ritmo alfa, pero se muestra más lento, su frecuencia es de cuatro a siete hertzios y aparece en las sensaciones de placer y de dolor, así como en los sueños y los estados de agresividad; también se puede decir que es un ritmo emocional. Se presentan repeticiones continuas con matrices de titilación, estroboscopía, fulguraciones, paroxísmica, vibración y barridos; respuestas autonómicas en patrones de reconocimiento y cambios fisiológicos activados por impulsos ultrarápidos en la retina y matrices rítmicas de repetición dirigidas al sistema nervioso; áreas de interacción óptica de formas, colores, sonidos y movimientos temporales transmitidas por estimulaciones fóticas; interrupción e introducción de imágenes sin interpretación concreta ni definición de su forma y naturaleza perceptual; video psicofísico, estructura subconsciente con respuestas variables entre desórdenes involuntarios y traumas epilépticos; ataques neuroactivos generados por patrones rítmicos alternados; exposición a un video psicotrópico por su estructura superconsciente con tendencias variables entre emotiva, concentrada y catatónica o alucinatoria; repetición transformacional con apariencias figurativas de imágenes con tratamientos distorsionantes y anamórficos en aspectos físicos contranaturales; aparente animación de imágenes sin correlación de continuidades; video análisis por reordenamiento y síntesis de fenómenos cinematográficos discontinuos o fragmentados; desdramatización y sujetos no predictivos que causan un sistema reflexivo particular; experiencia ilusoria producida por contrastes simultáneos e inducción de reacciones ópticas, sus consecuencias en el sistema autonómico nervioso presentan funciones preconscientes; la exposición a este video puede provocar respuestas desconocidas. 
Outro importante pioneiro latino-americano é o cubano Enrique Alvarez e o seu vídeo Espectador (1989) é considerado o primeiro exemplo de vídeo-arte cubana. Este trabalho lida com a ambigüidade da condição do espectador de televisão, de um lado auto-consciente de sua própria exterioridade com relação ao mundo televisivo e, de outro, prisioneiro da pequena tela, em decorrência dos mecanismos de projeção e identificação com que trabalha a mídia. Anne-Marie Duguet (1981, p.86) já havia observado que a perturbação dos signos visuais e sonoros da televisão, bem como o retalhamento e a desmontagem impiedosa de seus programas constituem a matéria de boa parte das pesquisas plásticas em vídeo. Daí porque não seria exagero dizer que a televisão tem sido o referente mais direto e mais freqüente da vídeo-arte nos seus mais de quarenta anos de história em todo o mundo. Alvarez é impiedoso com a televisão, inclusive com a televisão cubana, que, muito estranhamente, coloca no ar todos os enlatados norte-americanos, com base no argumento elementar de que, em decorrência do embargo econômico dos EUA, os cubanos não precisam pagar direitos de exibição! $O$ vídeo começa com um zapping pela programação televisiva e termina com um duelo mortal entre um protagonista de seriado policial e um espectador comum, cada um com sua arma favorita: um com uma pistola automática e o outro com um controle remoto. Alvarez ainda traria outras preciosas contribuições para a história da vídeo-arte cubana, como o vídeo Amor y Dollor (1990) e a vídeo-instalação El Malestar de Sofía (2004).

No ambiente argentino, Claudio Caldini é outro pioneiro cuja obra tem sido objeto de redescoberta e referência para as novas gerações. Entre 1970 e 1983, Caldini realizou uma obra bastante sólida em termos de experimentação audiovisual, utilizando o super-8 como bitola e low technology. Essa obra é considerada uma ponte entre o passado cinematográfico e o presente eletrônico. A partir dos anos 1990, Caldini adere ao vídeo, mas sempre com inserções cinematográficas, ainda que seu olhar e sua linguagem permaneçam sempre resolutamente contemporâneos. Dentre as quase duas dezenas de filmes experimentais realizados em super-8 por Caldini, podemos citar Oferenda (1978), uma espécie de dança das flores cintilante e multicromática, com resultados visuais quase abstratos. Trata-se de uma bela aula de edição e de sincronização imagem-som, orquestrada pelo mestre argentino do cinema experimental, com base na música de Alice Coltrane. 
Adán y Eva en el Paraiso de Judith Gutiérrez (1982) é uma pequena obra-prima em $16 \mathrm{~mm}$, realizada pelo equatoriano Paco Cuesta. Trata-se de um passeio pela obra da destacada pintora Judith Gutiérrez, também equatoriana, em que as figuras e paisagens do paraíso perdido ganham vida através do extraordinário trabalho de animação e da complexa sincronização sonora. O filme havia sido perdido e só recentemente se encontrou uma cópia em avançado estado de deterioração. Infelizmente, as fortes cores da pintura de Gutierrez se perderam com o tempo e hoje o filme só pode ser visto num colorido esmaecido. Posteriormente, Cuesta se dedicaria à direção de televisão, trabalhando no canal equatoriano Ecuavisa.

Também do Equador vem o nome de outro importante pioneiro do vídeo e cinema experimental: Miguel Alvear. Dentre as várias vertentes do trabalho desse realizador, uma das mais interessantes é o conceito desenvolvido por ele de película caseira, que seria um filme sem pretensões de construir um grande discurso sobre um grande tema da história, em troca de uma abordagem mais íntima, quase pessoal, de temas pequenos, quase sempre relacionados com a família e os amigos. É uma forma de explorar aquilo que é próprio das bitolas e dos formatos "amadores", como é o caso do super-8 e do vídeo VHS, durante muito tempo utilizados massivamente como dispositivos de preservação da memória familiar. A partir dos anos 1980, Alvear realizou uma série de películas que vão nessa direção (embora também tenha trabalhos com temáticas e estilos de outra ordem), como é o caso de Anima Mar (1990). A base desse filme/ vídeo é um material gravado muitos anos antes - em super-8 e sem som - da filha do realizador visitando pela primeira vez o mar, com ênfase no movimento e expressão de seus olhos, que pareciam revelar um misto de pânico e deslumbre. A película foi editada caseiramente com uma máquina de visualização e fita adesiva e, algum tempo depois, transferida a $16 \mathrm{~mm}$ através de uma optical printer, explorando o desgaste e os detritos produzidos sobre a emulsão pelo passar dos anos. Finalmente, mais algum tempo depois, ela foi transferida a vídeo e a ela o realizador acrescentou uma trilha sonora com o primeiro Arabesque, de Claude Debussy. Pura epifania.

Diego Risquez também tem seu nome ligado à história do super-8 na Venezuela, sendo possivelmente o seu mais eloqüente representante, mas vai na direção contrária de Alvear. Conseguiu uma coisa insólita, sobretudo em termos de América Latina, que 
é produzir longa-metragens em super-8, para depois transferilos a $35 \mathrm{~mm}$. Assim foram produzidos os longas Bolivar Sinfonía Tropical (1981) e Orinoko Nuevo Mundo (1984), além de Amérika Terra Incógnita (1988), este último um Super-16 mm transferido a $35 \mathrm{~mm}$, todos eles exibidos no Festival de Cannes! Todos os filmes de Risquez têm uma forte influência de Glauber Rocha, sobretudo na temática e na visualidade, embora sejam menos indisciplinados na forma. São produções caprichadas que enfocam sempre temas viscerais da história da Venezuela e de toda a América Latina, mas num estilo desdramatizado, à maneira brechtiana. A Propósito da Luz Tropical (1978) é uma homenagem (em super-8) ao pintor venezuelano Armando Reverón, o artista que, como um antropólogo natural, buscou representar a visão do homem tropical, esse homem cego de tanta luz. Reverón aparece inicialmente pintando sobre uma tela-espelho que reflete a luz tropical. Voltamos ao período branco do artista, onde nada se vê de forma distinta, todas as imagens estão "estouradas", dissolvidas no mar de luz, mas, ainda assim, pode-se distinguir vagas manchas daquilo que um dia poderiam ter sido figuras e paisagens. A Propósito é, enfim, uma radical experiência de incendiar a imagem.

Gastón Ugalde é um artista boliviano que trabalha sobre temas de seu país, utilizando sempre materiais (objetos, roupas, artesanato etc.) que dizem respeito à cultura própria da Bolívia, sobretudo das populações majoritárias indígenas. Seu ateliê em La Paz é também uma galeria de arte especializada em arte boliviana contemporânea, abrangendo trabalhos que vão da pintura e fotografia até as vídeo-instalações. Marcha por la Vida (1986/92), um de seus trabalhos mais eloqüentes, é uma obra em progresso, que já rendeu diversas versões e diversas associações a instalações. A obra está relacionada com a vida do homem andino e à problemática social da Bolívia. Ugalde associa os tecidos coloridos elaborados pelos índios das diferentes etnias do altiplano andino a valores culturais e políticos. Os tecidos, para os aimarás e incas bolivianos, assim como para os maias guatemaltecos, representam mais que mera vestimenta ou adorno; eles formam uma espécie de mídia têxtil (expressão criada por John Downing em seu livro Mídia Radical, 2002: 177/180): são formas de comunicação, de identidade e de manifestação política. Nessa obra, Ugalde associa a tessitura das mantas bolivianas à consciência coletiva e à resistência do povo contra a miséria e a opressão. 
Reconstruyen Crimen de la Modelo (1990) é uma obra que marca o encontro de dois dos mais importantes realizadores de vídeo da Argentina: Andrés di Tella e Fabián Hofman. O primeiro é um documentarista dos mais prestigiados, com uma extensa lista de trabalhos em seu currículo, donde se pode destacar, por exemplo, Dezaparición Forzada de Personas (1989), Montoneros, una Historia (1995) y La Television e Yo (2002). O segundo realizou trabalhos como Five Seconds (1982), Los Abuelos de la Nada en Obras (1983) e Subte Line (1985), todos em parceria com Carlos Trilnick, outro pioneiro da vídeo-arte na Argentina. A partir de 1996, Hofman migrou para o México, onde dirigiu o longa-metragem Panchito Rex (1999), que tem também uma versão interativa. Di Tella e Hofman juntos realizaram também 70 Metros (1989), 33 Millones de Financistas (1991) e Guía del Immigrante (1993). Reconstruyen parte de uma notícia de fait divers: uma modelo famosa foi assassinada e o suposto criminoso preso pela polícia. Mas não há imagens desse drama. Durante a acareação, o criminoso é constrangido a fazer uma reconstituição do crime, no local onde ocorreu, substituindo a vítima por uma mulher policial. Ávido de sensacionalismo, o Nuevodiario, telejornal do Canal Nueve portenho, grava a reconstituição e a edita com requintes de dramaticidade, acompanhada de uma tensa trilha sonora, como se o fato, a reconstituição e o informe televisivo coincidissem. Por fim, os dois realizadores gravam o programa em suas casas e depois o reeditam em câmera lenta e com distorção sonora, desconstruindo a versão televisiva da versão policial de um fato cuja verdade nunca conheceremos inteiramente. Uma imensa acumulação de simulacros marca esse vídeo antológico, que gerou profundos debates sobre a natureza da verdade e o papel das mídias na construção da realidade.

Por fim, Enrique Colina é um realizador cubano de semidocumentários e também professor da Escuela de Cine y TV de San Antonio de los Baños, além de apresentador de um programa de televisão sobre cinema, muito conhecido em Cuba. Dizemos semi-documentários porque os "documentários" de Colina, além de muito bem humorados, não têm pudores de acrescentar cenas reconstruídas, partes de ficção, fragmentos de filmes e programas de televisão e toda sorte de hibridismos, que os torna de impossível classificação. A extensa filmografia de Colina está sempre vinculada a uma falsa pretensão de "educar" o cubano para os valores 
da cidadania, embora, no fundo, ele se utilize desses pequenos filmes aparentemente institucionais para fazer uma dura reflexão sobre o fracasso da Revolução Cubana. Entre seus filmes mais conhecidos, podemos citar: Estética (1984), Vecinos (1985), Mas Vale Tarde que Nunca (1986), Yo También Te Haré Llorar (1984), Jau (1986) e El Rey de la Selva (1991).

Chapucerías (1986) é talvez o filme mais emblemático da obra de Colina. Em espanhol, chapucería é o nome que se dá a qualquer trabalho de má qualidade, servindo também para designar o embuste e a picaretagem. A pretexto de denunciar o "chapucero" como o incompetente que transforma tudo em destroços e sucata, o filme acaba funcionando como uma metáfora de um país que fracassou. Trata-se de uma comédia inclemente, disfarçada de documentário, em que o "chapucero" aparece como um monstro dos filmes americanos de terror dos anos 1930 e 40. O filme é construído como se fosse um quest show de televisão com perguntas e respostas sobre os tais monstros. Contaminado pelo próprio mal que denuncia, até mesmo o filme termina destruído pela má qualidade do trabalho de seus realizadores.

Esta pequena panorâmica dos vídeos e filmes experimentais latino-americanos é evidentemente incompleta, como não poderia deixar de ser, sobretudo considerando a escassez de informação de que dispomos até o momento e os limites de páginas de um artigo. Ficaram de fora nomes fundamentais, como os dos colombianos Carlos Mayolo e Luis Ospina, do costa-riquense Manuel Zumbado, do chileno Nestor Olhagaray, da mexicana Ximena Cuevas, do argentino Carlos Trilnick, dos brasileiros Arthur Omar e Edgar Navarro, do venezuelano Carlos Castillo, entre outros e apenas para considerar os "históricos". Faltaram também nomes consagrados, como os dos chilenos Juan Downey e Raul Ruiz, do porto-riquenho Edin Velez, da cubana Tania Bruguera, dos argentinos Marta Minujin e Jaime Davidovich, que, malgrado latino-americanos de origem, desenvolveram a maior parte de suas obras no exterior, sobretudo nos Estados Unidos (França, no caso de Ruiz). Mas podemos encarar as primeiras tentativas de abordar o vídeo e o cinema experimental latino-americano como o início de uma longa trajetória na direção da necessária recuperação de uma história que não foi ainda contada. Um povo sem memória é um povo sem história. 


\section{Bibliografia}

ADRIANO, Carlos. 2007. "O Específico Brasil".

Caderno Sesc/Videobrasil, São Paulo, n. 3.

AGUERRE, Enrique. 2007. La Condición Video.

Montevideo: Centro Cultural de España.

BAIGORRI, Laura (org.). 2008. Video en Latinoamérica: una

Historia Crítica. Madrid: Brumaria.

DOWNING, John. 2002. Mídia Radical. São Paulo: Senac.

DUGUET, Anne-Marie. 1981. Vidéo, la mémoire au poing.

Paris: Hachette.

FERREIRA, Jairo. 1986. Cinema de Invenção.

São Paulo: Max Limonad.

KRAUSS, Rosalind. 1978. Video: the Aesthetics of Narcissism.

In: BATTOCK, Gregory (ed.). New Artists Video.

New York: Dutton.

LA FERLA, Jorge (org.). 2008. Historia Crítica del Video

Argentino. Buenos Aires: Malba/Telefónica.

MOREIRA CRUZ, Roberto (org.). 2008. Visionários: Audiovisual na América Latina. São Paulo: Itaucultural.

PARANAGUÁ, Paulo. 2003. Tradición y Modernidad en el Cine de América Latina. México: Fondo de Cultura Económica.

RENAN, Sheldon. 1970. Uma Introdução ao Cinema

Underground. Rio de Janeiro: Lidador.

VILLACORTA, Jorge y José-Carlos Mariátegui. 2005.

Videografías Invisibles. Valladolid: Patio Herreriano.

YOUNGBLOOD, Gene. 1970. Expanded Cinema.

New York: Dutton. 